肺音聴診シミュレータ“Mr. Lung”を用いた新しい医学教育

吉井 千春 ${ }^{1}$, 安西 崇 ${ }^{2}$, 矢寺 和博',

川尻龍典 ${ }^{1}$, 中島 康秀 ${ }^{3}$, 城戸 優光 ${ }^{1}$

'産業医科大学医学部 呼吸器病学教室

${ }^{2}$ 株式会社 京都科学 教育機器部

3産業医科大学医学部 第 2 内科学教室

要 旨：当教室と株式会社京都科学で共同開発した肺音聴診シミュレータ“Mr. Lung” を実際の医学教育で使用し，教育効果を確認した，対象は産業医科大学医学 部 5 年生100名. 臨床実習でローテートしてきた学生に対し,90分間の肺音聴 診教育を行った．最初に肺音分類の概説を行った後， 3 症例についてシミュ レータに聴診器をあてて聴診し, 肺音の「異常の部位·種類」を解答させ, 解 答の解説と鑑別方法を説明した。また聴診教育の前後で 5 段階法による聴診 能力の自己評価を行った. その結果, 聴診の正答率は, 呼吸音の左右差; $36.9 \%$, coarse crackles; $52.5 \%$, fine crackles; $34.1 \%$, wheezes; $69.2 \%$, rhonchi; $62.1 \%$,

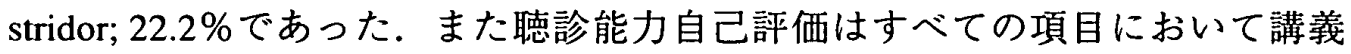
後に有意に高得点を示した．学生の肺音聴診能力は教育者側の予想以上に悪 く,シミュレータを用いた繰り返しの聴診教育が必要と考えられた.

（2002年 5 月 14 日 受付, 2002年 7 月 16 日 受理)

はじめに

臨床能力評価法として，近年客観的臨床能 力試験 (objective structured clinical examination: OSCE)が急速に普及してきている[1]。この 中で呼吸器の身体診察は, 視診, 触診, 打診, 聴診の手順が評価されるが, 聴打診の手技が 特に重要である。これまで呼吸器疾患の聴診 教育にはカセットテープや $\mathrm{CD}[2,3]$ が多く 用いられていたが,これらは音の種類を学習 することは出来ても, 胸部における音の拡が りや病変部位との対応を立体的に理解するに は不十分であった。こうした欠点を補うため， 1999年より当教室と株式会社京都科学で肺音
聴診シミュレータの開発に着手し，2001年に 日本語版 [4]，英語版をともに完成させた。 これらはそれぞれ “Mr. Lung”, “Lung Sound Auscultation Trainer(LSAT)”という商品名(京 都科学)である。

今回, 実際のベッドサイド教育で“Mr. Lung” を使用して, 教育的有用性の検討と今後の利 用法の模索を行った。

\section{対象と方 法}

対象は2001年 6 月から2002年 3 月までに臨 床実地教育で当教室と第 2 内科学教室にロー テートしてきた産業医科大学医学部 5 年生の 学生100名.1グループは 5 名ないし 6 名で 
2 週間のカリキュラムで主に呼吸器, 循環器, 腎臓を主体とした内科学の習得を目標として いるが，この中で90分間を肺音聴診教育にあ てた。

\section{1.方法}

最初に肺音分類 [6]についてのプリントを 配布し概説した．その後, 2〜3名ずつ一般診 療に用いられる聴診器で, “Mr. Lung”を聴診
した。肺音聴診シミュレータ“Mr. Lung”（Fig. 1) はマネキン部のシミュレータ本体, ディ スプレイ, コンピュータ本体, キーボード, マウスからなり, ディスプレイ画面 (Fig. 2) で症例を選択し，シミュレータに肺音を出す ことが出来る。本実習ではディスプレイ部を 学生に見られないように配置して操作し, 学 生はマネキン部の前胸部および背部に聴診器 をあてて診察した。選択した 3 症例の肺音に

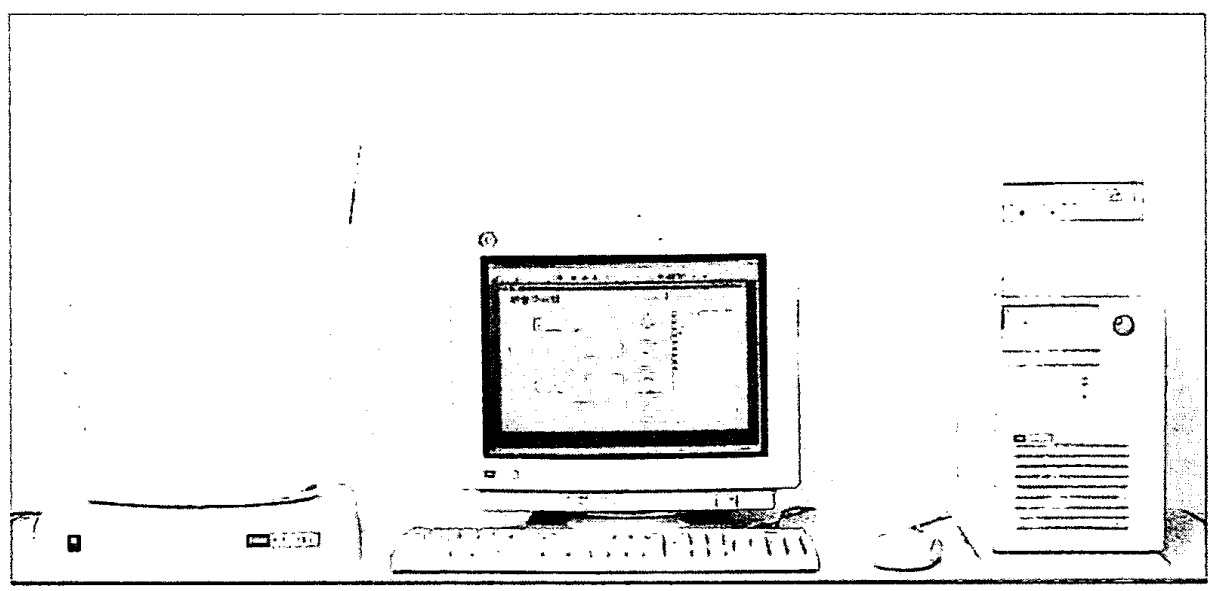

Fig. 1. Total image of the simulator. It consists of human-sized manikin torso, computer's display, keyboard, mouse and main body of the computer.

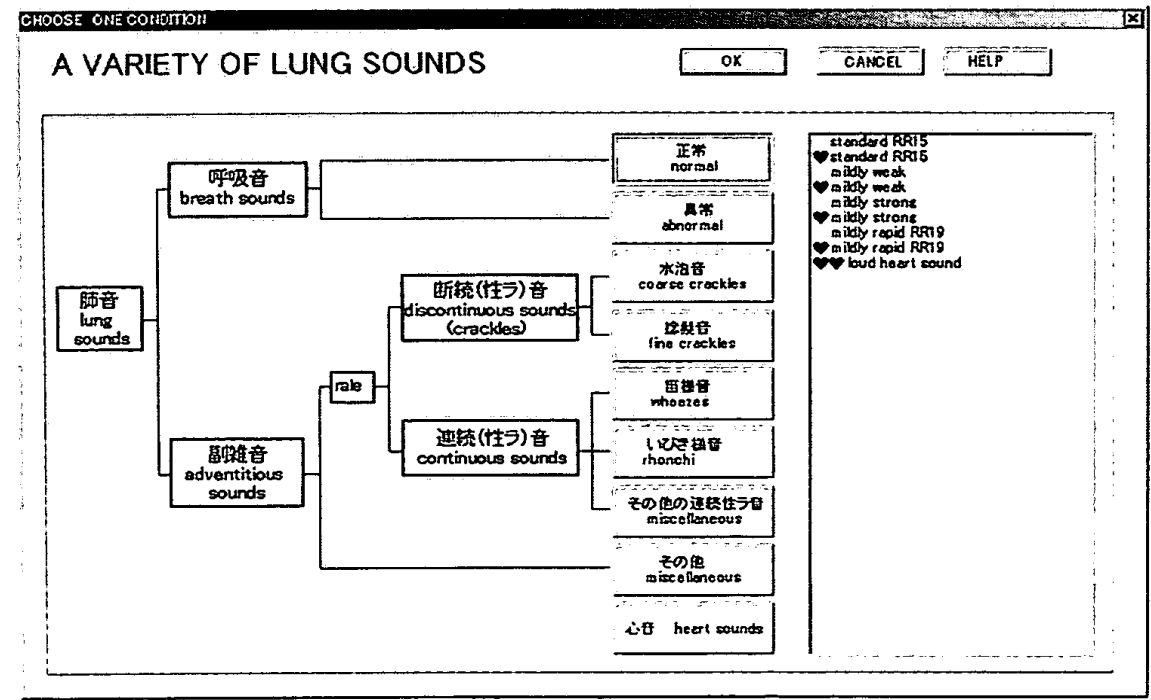

Fig. 2. The classification of lung sounds demonstrated on the computer's display. 
ついてその異常部位と異常の種類を小テスト 形式で学生に解答させた。その後肺音の恥診 能力自己評価を, 肺音の左右差, coarse crackles, fine crackles, wheezes, rhonchi, stridor の 6 項目について 5 段階法(「1」が聴診出来な い.「2」が少し聴診できる。「3」が普通に聴診 できる．「4」が少し自信を持って聴診できる， 「5」が自信を持って聴診できる)で記入させ回 収した。次にコードレス聴診教育システム

“HI-STETHO” (泰斗工研, 東京)を使用して “Mr. Lung”の肺音を全員で同時に聴診しな がら， 3 症例の解説を行うとともに, 鑑別上 重要な他の異常音やラ音の聴診も行った. 最 後の数分で再度5段階法による聴診能力自己 評価を行い，実習の前後で比較した。また実 習前後での比較を統計学的に paired t-test 用いて検討し， $P<0.05$ を有意と判定した。

\section{結果}

\section{1.肺音聴診テストの正答率(Fig. 3 ).}

正答率を 6 項目につき検討した. 肺音の左 右差は $36.9 \%$ (84名中31名正解), coarse crackles は53.5\% (61名中32名正解), fine crackles は
$34.1 \%$ (44名中15名正解), wheezesは69.2\% (36 名中18名正解), rhonchi は62.1\% (58名中36名 正解)， stridor は $22.2 \%$ (27名中 6 名正解)で あった。

2 . 奏習前後の聴診能力自己評価(Fig. 4 ).

呼吸音の左右差, coarse crackles, fine crackles, wheezes, rhonchi, stridorの全ての項目 において，実習後で有意に $(P<0.0001)$ 高く なった．特にこの傾向は rhonchi と stridor で 著明であった。

考察

本邦において医学教育を目的とした聴診シ ミュレータは,マネキン型の心臓病患者シミ ユレータ (京都科学) [6]があり，その教育効 果の評価が固まりつつある $[7,8]$. 肺音シミ ユレータは，これまで本邦の医学教育で本格 的に使用されたことはなく，海外では肺音を シミュレートした音をコンピュータに発生さ せる方法[9]が主流である。マネキン部に多 数のスピーカを内蔵し[4], 実際の患者から 録音した肺音を再生する“Mr. Lung”ゃ

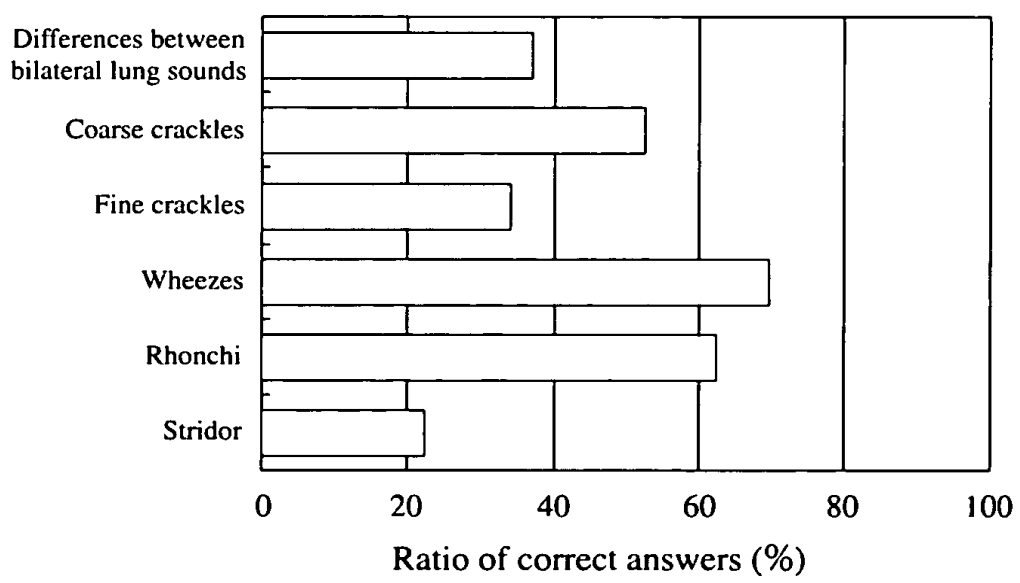

Fig. 3. Identification rates $(\%)$ in various lung sounds. 
“LSAT”型の肺音シミュレータを医学教育 の場で使用したのは本学が初めてである.

学生はべッドサイド教育が始まる前の診断 学実習で, 胸部の聴診と肺音の分類に関する 教育を既に一度受けている。また当教室に ローテートしてきた際, 肺音聴診実習より前 に，病棟回診や外来実習でコードレス聴診教 育システム“HI-STETHO”を用いて，患者の 心音や肺音を聴いており, 特徵的な副雑音は 複数回聴診している。しかしながら, 肺音聴 診実習での小テストの結果は決して満足出来 るものではなかった．検討した項目で「肺音 の左右差」とは，気胸や胸水貯留などで片側 肺の呼吸音が減弱ないし消失している症例で, 肺音の左右差を比較するという基本的手技が
行われているかを知る意味で重要な項目であ る。また気胸のような疾患は胸部 X 線写真 を撮って初めて確定診断されるものであるが, その前の理学所見の段階で異常を認識出来る かが重要である，その意味でこの項目の正答 率が36.9\%と低いのは極めて深刻な問題と思 われた. coarse crackles と fine crackles では両 者の取り違いによる誤答が目立った. stridor は吸気時に連続性ラ音を聴取するものである が，主に呼気時に聞かれる wheezes との鑑別 がポイントとなる． stridorを呈する疾患が上 気道閉塞や気管内腫痬・異物といった直接生 命に関わるものが多いため，これを wheezes =気管支喘息と判断すると大きな誤診につな がる。 その意味で stridorの正答率 $22.2 \%$ も

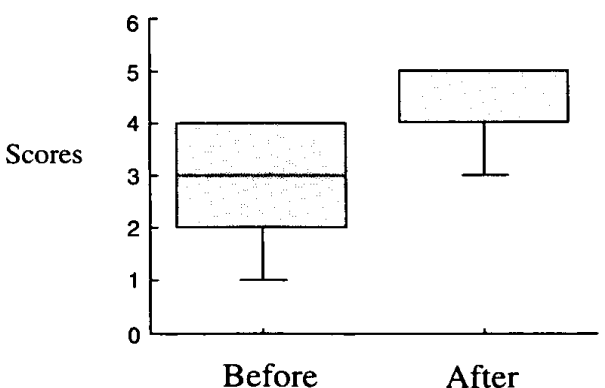

Wheezes

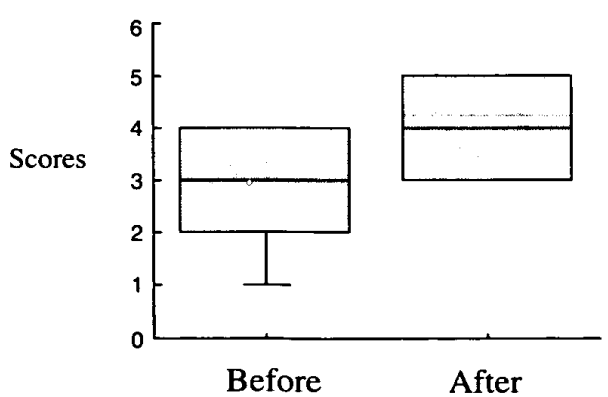

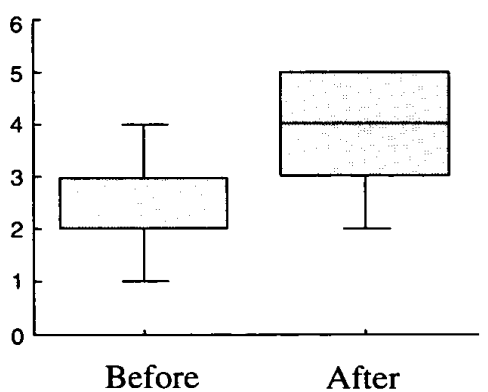

Rhonchi

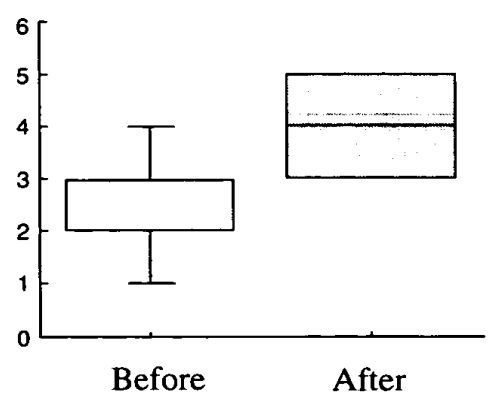

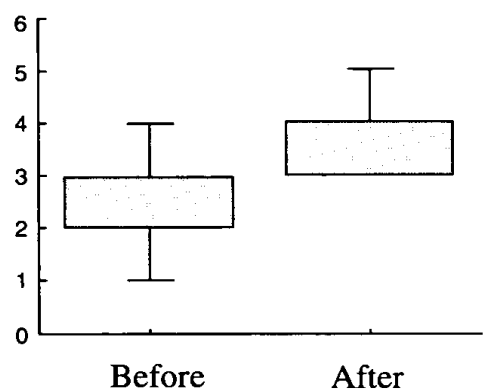

Stridor

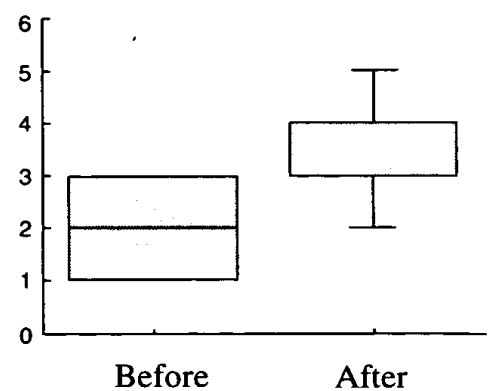

Fig. 4. Self-assessment scores before and after the pulmonary auscultatory class. The scores are significantly $(P<0.0001)$ higher after the class than before. 
た渵足のいく結果ではなかった.

Mangione ら[10]は，アメリカ合衆国にお いて194名の医学生, 387名の内科研修医, 240 名の家庭医研修医, 18名の呼吸器科修錬医 の肺音聴診能力をテストした。その結果医学 生の正答率は“bronchial breath sounds”で55\%, "vesicular breath sounds + late-inspiratory crackles" で20\%, "expiratory wheezes" で80\%, "expiratory rhonchus”で20\%などの結果で，これらは内 科や家庭医の研修医も同様の結果であった。

このことは本学の医学生に限らず，肺音聴診 能力は決して高いものではなく，また研修医 になっても現在の教育体制では聴診能力が向 上するものではないことを意味している。ま た Mangione ら [11]は，別の報告で医学部 3 年生 (日本では 5 年生に相当)に対して聴診教 育を行った群と全く行わなかったコントロー ル群で学年末に行われたOSCEでの聴診能 力を比較した。聴診教育群は週 1 時間で心音 3 単位, 肺音 1 単位の延べ 4 週間にわたって 録音した音の認識や解釈のトレーニングを補 習授業として受けた。一方コントロール群で は従来からの内科の講義が行われ，聴診の補 習授業は一切行わなかった。聴診教育群45名 とコントロール群21名での正答率は“bronchial breath sounds"で40 vs $38 \%$, "late inspiratory crackles" で98 vs $90 \%$, "pleural friction rub" で38 vs $19 \%$, "bronchial breath sounds + late inspiratory crackles”で24 vs 14\%であった.こ れらの結果から聴診教育群の成績が概してコ ントロール群より良い傾向がみられたが，有 意差には至らなかった。この論文の中で Mangioneは繰り返し行う聴診教育の重要性を強 調しているが，患者を用いた繰り返しは現実 的ではなく, 電子音やシミュレータが教育上 有用であると述べている。正味 1 時間の肺音 聴診補習授業の結果をふまえると, 当教室が 開発したシミュレータで繰り返し肺音を聴診 したならば，さらなる教育効果が期待される
ものと思われる。

今回, 肺音聴診シミュレータを用いた聴診 教育の有用性について, 実習前後に行った聴 診能力自己評価で検討し, 実習後の自己評価 点が実習前より有意に高い結果が得られた。

特に rhonchi と stridorで実習前後の差が大き かったが，これは両者が病棟回診や外来実習 あるいは受け持ち患者で聴診する機会が少な いため, シミュレータでの実習が特に有用で あったと推測される。学生の自己評価による 本シミュレータの教育効果の検討は客観性に 欠ける難点があるが, 少なくとも学生自身が 感じる教育効果には大いに奇与しているもの と思われた。

他大学に先駆けて本学で肺音聴診シミュ レータを用いた聴診教育を行ったが，今後の 検討課題としては，教育効果のより客観的評 価の必要性があげられる。このためには教育 的介入を行った群と行わない群で差を検討す る[11]のが理想ではあるが，むしろ時間をあ けて 2 回の聴診能力試験や自己評価[8]を行 う方が現実的と思われる。今回はシミュレー 夕が1台しかなかったことや実習時間の関係 で，実習前後での 2 度のテストが出来なかっ た。 5,6名のグループ教育では, 少なくとも 2 台使用することにより, 時間的余裕が出来 て2度のテストが可能になるかも知れない. また肺音の識別(lung sound recognition) のみ ならず，聴診から診断にまで踏み込んだ評価 (lung disease identification) [11]を行う必要が あると考えられた。さらに可能ならば，時間 をあけて系統的な教育を繰り返し行うのが理 想であるが，学生のローテート期間中や研修 医の研修期間中も自由にシミュレータに触れ， 自学自習出来る環境を整備することも必要と 思われた。 


\section{引用 文 献}

1. 伴信太郎 (1995): 客観的臨床能力試験一臨床能力の新しい評価法一。医学教育 26: $157-163$

2. 川城丈夫, 阿部 直, 菊池功次, 米丸 亮, 石原恒夫 (1993): CD よよる聴診トレーニング. 南光堂, 東京 $\mathrm{CD}$

3. ダイアン・M・ズロンカー, トーマス・A・ブラックウェル, バージニア・バトラー (1993): 呼吸音のアセスメント。へるす出版, 東京 $\mathrm{CD}$

4. 吉井千春, 安西 崇, 松元優子, 大南諭史, 伊藤寿朗, 川尻龍典, 林 俊成, 今永知俊, 城戸優光 (2001)：医学教育用肺音シミュレータの作製。呼吸 20：813-818

5. 三上理一郎 (1985)：ラ音の分類と命名. 日医師会誌 94：2050-2055

6. Takashina T, Shimizu M \& Katayama H (1997): A new cardiology patient's simulator. Cardiology 88: $408-413$

7 . 高階經和（1998）：新しい心臓病患者シミュレータ“Ichiro”とその診断手技向上における教 育効果. 医学教育 29: 227-231

8. 伊賀幹二, 小松弘幸, 石丸裕康 (2001)：医師免許取得後早期より反復して行った心臟病患 者シミュレーターを用いた診察実習の効果。医学教育 32: 107ー-111

9. Kompis M \& Russi EW (1997): Computer-based lung sound simulation. Med Biol Eng Comput 35: $231-238$

10. Mangione S \& Nieman LZ (1997): Pulmonary auscultatory skills during training in internal medicine and family practice. Am J Respir Crit Care Med 159: 1119-1124

11. Mangione S, O’ Brien MY \& Peitzman SJ (1997): Innovation in medical student education. Acad Med 72: S $121-\mathrm{S} 123$ 


\title{
A New Medical Education using a Lung Sound Auscultation Simulator called "Mr. Lung"
}

\author{
Chiharu YoshII', Takashi ANZAI², Kazuhiro YATERA', \\ Tatsunori KAWAJIRI', Yasuhide NAKASHIMA ${ }^{3}$ and Masamitsu KIDO' \\ 'Department of Respiratory Disease, School of Medicine, University of Occupational and Environmental \\ Health, Japan. Yahatanishi-ku, Kitakyushu 807-8555, Japan \\ ${ }^{2}$ Department of Medical Educational Instrument, Kyoto Kagaku Co. Ltd., Fushimi-ku, Kyoto 612-8393, \\ Japan \\ ${ }^{3}$ Second Department of Internal Medicine, School of Medicine, University of Occupational and Environ- \\ mental Health, Japan. Yahatanishi-ku, Kitakyushu 807-8555, Japan
}

Abstract: We developed a lung sound auscultation simulator "Mr. Lung" in 2001. To improve the auscultation skills of lung sounds, we utilized this new device in our educational training facility. From June 2001 to March 2002, we used "Mr. Lung" for our small group training in which one hundred of the fifth year medical students were divided into small groups from which one group was taught every other week. The class consisted of ninety-minute training periods for auscultation of lung sounds. At first, we explained the classification of lung sounds, and then auscultation tests were performed. Namely, students listened to three cases of abnormal or adventitious lung sounds on "Mr. Lung" through their stethoscopes. Next they answered questions corresponding to the portion and quality of the sounds. Then, we explained the correct answers and how to differentiate lung sounds on "Mr. Lung". Additionally, at the beginning and the end of the lecture, five degrees of self-assessment for the auscultation of the lung sounds were performed. The ratio of correct answers for lung sounds were $36.9 \%$ for differences between bilateral lung sounds, $52.5 \%$ for coarse crackles, $34.1 \%$ for fine crackles, $69.2 \%$ for wheezes, $62.1 \%$ for rhonchi and $22.2 \%$ for stridor. Self-assessment scores were significantly higher after the class than before. The ratio of correct lung sound answers was surprisingly low among medical students. We believe repetitive auscultation of the simulator to be extremely helpful for medical education.

Key words: medical education, auscultation, lung sounds, simulator, "Mr. Lung"

J UOEH 24 (3): 249-255 (2002) 